\title{
Kinerja Aparat Penegak Hukum dalam Penanganan Perkara Tindak Pidana Korupsi di Provisi Kalimantan Selatan
}

\author{
Rudi Indrawan , H. Ahmad Syaufi \\ Fakultas Hukum Universitas Lambung Mangkurat \\ dyindrawanfhunlam@gmail.com
}

\begin{abstract}
Effectiveness of law enforcement must pay attention to two (2) it is very important that the first factor and the second law is the law enforcement apparatus. This means that in addition to legal factors must be good, law enforcement officers must also be able to act professionally and proportionately in handling corruption cases. This research is to answer the question of how the performance of law enforcement officers, inhibiting factors and supporting the performance of law enforcement agencies (police and prosecutors) in dealing with corruption cases in the province of South Kalimantan. In connection with these problems, this research aims to seek enforcement model that can be accommodated in the handling of corruption. The results showed that the apparatus performance in this case the police and the AGO in South Kalimantan province already provide maximum results even though there are still some obstacles. Related enforcement model that can be accommodated on the handling of corruption is coordinated models and regulatory models.
\end{abstract}

Key Word : Corruption, performance, law enforcement officers, handling model.

\begin{abstract}
Abstrak
Efektifitas penegakan hukum harus memperhatikan 2 (dua) hal yang sangat penting yaitu pertama faktor hukumnya dan yang kedua yaitu faktor penegak hukumnya. Artinya selain faktor hukumnya harus baik, aparat penegak hukumnya juga harus mampu bertindak secara profesional dan proporsional dalam penanganan perkara tindak pidana korupsi. Penelitian ini untuk menjawab permasalahan bagaimana kinerja aparat penegak hukum, faktor penghambat dan penunjang kinerja aparat penegak hukum (kepolisian dan kejaksaan) dalam menangani perkara tindak pidana korupsi di Provinsi Kalimantan Selatan. Berkaitan dengan permasalahan tersebut maka penelitian ini bertujuan mencari model penegakan yang dapat diakomodasikan dalam penanganan tindak pidana korupsi. Hasil penelitian menunjukkan bahwa Kinerja Aparat yang dalam hal ini Kepolisian dan Kejaksaan di Provinsi Kalimantan Selatan sudah memberikan hasil yang maksimal meskipun masih terdapat beberapa kendala. Terkait Model penegakan yang dapat diakomodasikan dalam hal penanganan tindak pidana korupsi adalah model koordinatif dan model regulatif.
\end{abstract}

Kata Kunci : Korupsi, kinerja, aparat penegak hukum, model penanganan. 


\section{Pendahuluan}

Permasalahan korupsi di Indonesia dapat dikatakan sudah dalam taraf yang membahayakan. Korupsi terjadi hampir di seluruh lapisan, baik di lembaga pemerintah, perwakilan rakyat, peradilan, pengusaha maupun masyarakat. Korupsi di Indonesia sudah bersifat sistemik, artinya tindak pidana itu dilakukan di semua lembaga negara dari tingkat paling rendah sampai yang paling tinggi. Selain itu, korupsi juga terjadi di lembaga penegak hukum yang seharusnya menegakkan hukum. Hal ini berarti korupsi memiliki akibat yang sangat luas. Menurut Muladi, dampak luas korupsi terhadap Indonesia berupa:

a. merendahkan martabat bangsa di forum internasional.

b. menurunkan kepercayaan investor, baik domestik maupun asing; bersifat meluas (widespread) di segala sektor pemerintahan (eksekutif, legislatif, dan yudikatif), baik di sektor pusat maupun daerah;

c. bersifat transnasional dan bukan lagi masalah per negara;

d. cenderung merugikan keuangan negara dalam jumlah yang signifikan;

e. merusak moral bangsa (moral and value damage); f. menghianati agenda reformasi;

g. menggangu stabilitas dan keamanan negara;

h. mencederai keadilan dan pembangunan yang berkelanjutan (sustainable development);

i. menodai supremasi hukum (jeopardizing the rule of law);

j. semakin berbahaya karena bersinergi negatif dengan kejahatan ekonomi lain, seperti "money laundering";

k. bersifat terorganisasi (organize crime) yang cenderung transnasional;

1. melanggar HAM (Muladi, 2006 :1$3)$.

Skor Indeks Persepsi Korupsi Indonesia dalam 2 (dua) tahun terakhir (2012-2013) stagnan pada angka 32 dari $\begin{array}{llll}\text { skala } & 0 & \text { sampai } & 100\end{array}$ (http://nasional.kompas.com/read/2014/0 1/03/1547079/Mendongkrak.Indeks.Pers epsi.Korupsi, diakses tangal 12 Juli 2014.). bukan berarti upaya pemberantasan korupsi di Indonesia tidak dilakukan. Upaya pemerintah dilaksanakan melalui berbagai kebijakan berupa peraturan perundang-undangan yang mendukung pemberantasan korupsi. Selain itu, pemerintah juga membentuk komisi-komisi yang berhubungan 
langsung dengan pencegahan dan pemberantasan tindak pidana korupsi seperti Komisi Pemeriksa Kekayaan Penyelenggara Negara (KPKPN) dan Komisi Pemberantasan Korupsi (KPK). Upaya pencegahan praktek korupsi juga dilakukan di lingkungan eksekutif atau penyelenggara negara, dimana masingmasing instansi memiliki Internal Control Unit (unit pengawas dan pengendali dalam instansi) yang berupa inspektorat. Fungsi inspektorat mengawasi dan memeriksa penyelenggaraan kegiatan pembangunan di instansi masing-masing, terutama pengelolaan keuangan negara, agar kegiatan pembangunan berjalan secara efektif, efisien dan ekonomis sesuai sasaran. Di samping pengawasan internal, ada juga pengawasan dan pemeriksaan kegiatan pembangunan yang dilakukan oleh instansi eksternal yaitu Badan Pemeriksa Keuangan (BPK) dan Badan Pengawas Keuangan Pembangunan (BPKP).

Penegakan hukum tindak pidana korupsi menjadi hal yang fundamental saat ini, karena menjadi sebuah kebijakan nasional bagi penegakan hukum di Indonesia. Berbicara mengenai penegakan hukum tindak pidana korupsi tentunya semua akan kembali dalam suatu sistem yang kemudian kita sebut sebagai criminal justice system atau sistem peradilan Pidana. Suatu sistem yang dimulai dengan peristiwa hukum tindak pidana untuk kemudian melalui proses penyelidikan dan penyidikan yang menghasilkan suatu berita acara pemeriksaan (BAP) yang akhirnya menjadi suatu produk dakwaan ataupun tuntutan yang kemudian diperiksa dalam sebuah persidangan di Pengadilan sehingga menjadi suatu vonis atau putusan yang berkekuatan tetap untuk dijalankan dalam bentuk pemasyarakatan bagi pelaku tindak pidana tersebut. Pada hakekatnya perangkat penegak hukum terutama hukum pidana dalam criminal justice system atau sistem peradilan pidana di Indonesia adalah Kepolisian dan Kejaksaan. Kedua institusi ini merupakan state main organs penegakan hukum di Indonesia, termasuk tindak pidana korupsi.

Efektifitas didalam penegakan hukum ada dua hal yang sangat penting untuk diperhatikan yaitu pertama faktor hukumnya dan yang kedua yaitu faktor penegak hukumnya. Kedua faktor ini yang akan menentukan efektifitas dalam 
pemberantasan tindak pidana korupsi.

Artinya selain faktor hukumnya harus baik, aparat penegak hukumnya juga harus mampu bertindak secara profesional dan proporsional dalam penanganan perkara tindak pidana korupsi.

Berkaitan dengan itu, maka perlu dilakukan pengkajian terhadap kinerja aparat penegak hukum dalam penanganan perkara tindak pidana korupsi di Provinsi Kalimantan Selatan, termasuk faktor penunjang dan penghambatnya sehingga akan ditemukan model yang ideal penanganan perkara tindak pidana korupsi yang efektif di Provinsi Kalimantan Selatan.

Berdasarkan uraian yang telah dikemukakan diatas maka dirumuskan permasalahan sebagai berikut:

1. Bagaimana kinerja aparat penegak hukum (kepolisian dan kejaksaan) dalam penanganan perkara tindak pidanan korupsi di Provinsi Kalimantan Selatan?

2. Faktor-faktor apa yang menjadi penunjang dan penghambat kinerja aparat penegak hukum (kepolisian dan kejaksaan) dalam menangani perkara tindak pidana korupsi di Provinsi Kalimantan Selatan?
3. Bagaimana model yang ideal bagi aparat penegak hukum dalam penanganan perkara tindak pidana korupsi di Provinsi Kalimantan Selatan?

\section{Tujuan Penelitian}

Sesuai dengan rumusan masalah diatas, maka yang menjadi tujuan dalam penelitian ini adalah:

1. Untuk menganalisis kinerja aparat penegak hukum (kepolisian dan kejaksaan) dalam penanganan perkara tindak pidanan korupsi di Provinsi Kalimantan Selatan.

2. Untuk menganalisis faktor-faktor yang menjadi penunjang dan penghambat kinerja aparat penegak hukum (kepolisian dan kejaksaan) dalam menangani perkara tindak pidana korupsi di Provinsi Kalimantan Selatan.

3. Untuk menganalisis dan merekonstruksi model yang ideal bagi aparat penegak hukum dalam penanganan perkara tindak pidana korupsi di Provinsi Kalimantan Selatan. 


\section{Metode Penelitian}

\section{Jenis Penelitian}

Permasalahan pokok yang akan diteliti dalam penelitian ini adalah penegakan hukum tindak pidana korupsi di Provinsi Kalimantan Selatan dengan metode penelitian yang digunakan adalah penelitian kualitatif.

Penelitian kualitatif merupakan prosedur penelitian yang menghasilkan data deskriftif berupa kata-kata tertulis atau lisan dari orang-orang dan perilaku yang dapat diamati, dan pendekatan ini diarahkan pada latar dan individu secara holitistik (utuh) (Moleong, 1997 : 3).

\section{Jenis Data Penelitian}

Jenis data penelitian yang dipergunakan dalam penelitian ini meliputi data primer dan data sekunder. Data primer diperoleh dari Anggota Kepolisian, Anggota Kejaksaan yang bertugas menangani perkara tindak pidana korupsi di wilayah hukum Kalimantan Selatan, Anggota BPK, Anggota BPKP wilayah Kalimantan Selatan dan perwakilan tokoh masyarakat.

Sedangkan data sekunder berupa bahan hukum primer yaitu : 1) Kitab Undang-Undang Hukum Pidana; 2) Undang-Undang Nomor 8 Tahun 1981 tentang Hukum Acara Pidana; 3) Undang-Undang Nomor 31 Tahun 1999 tentang Pemberantasan Tindak Pidana Korupsi; 4) Undang-Undang Nomor 20 Tahun 2001 tentang Perubahan atas Undang-Undang Nomor 31 Tahun 1999 tentang Pemberantasan Tindak Pidana Korupsi; 5) Undang-Undang Nomor 2 Tahun 2002 tentang Kepolisian Negara Republik Indonesia; 6) Undang-Undang Nomor 30 Tahun 2002 tentang Komisi Pemberantasan Tindak Pidana Korupsi; 7) Undang-Undang Nomor 16 Tahun 2004 tentang Kejaksaan Republik Indonesia. Bahan hukum sekunder terdiri atas : 1) Buku-buku literatur yang berkaitan dengan permasalahan yang dikaji dan dianalisa; 2) Karya tulis ilmiah berupa laporan hasil penelitian, jurnal ilmiah, dan lain-lainnya yang ada keterkaitan dengan permasalahan penelitian ini.

\section{Populasi dan Sampel}

Populasi yang dijadikan objek penelitian adalah : a) Penyidik yang bertugas di wilayah hukum Kepolisian Daerah Kalimantan Selatan yang bertugas menangani perkara tindak pidana korupsi di Provinsi Kalimantan Selatan ; b) Penyidik dan Jaksa Penuntut Umum pada Kejaksaan di wilayah 
Kalimantan Selatan yang bertugas menangani perkara tindak pidana korupsi di Provinsi Kalimantan Selatan;

c) Auditor BPK Perwakilan Kalimantan Selatan ; d) Auditor BPKP Wilayah Kalimantan Selatan; e) Perwakilan tokoh masyarakat di Kalimantan Selatan yang konsen pada penegakan hukum tindak pidana korupsi.

Berdasarkan pada populasi diatas, maka ditetapkanlah sampel penelitian sebagai berikut:

a. Penyidik kepolisian di bidang tindak pidana korupsi pada:

1. Penyidik Subdit Tipikor Polda Kalimantan Selatan.

2. Penyidik Unit Tipikor Polresta Banjarmasin.

3. Penyidik Unit Tipikor Polres Rantau.

4. Penyidik Unit Tipikor Polres Batulicin

b. Penyidik dan Jaksa Penuntut Umum di bidang tindak pidana korupsi pada:

1. Penyidik dan Jaksa Penuntut Umum Aspidsus Kejati Kalsel.

2. Penyidik dan Jaksa Penuntut Umum Kasipisus Kejari Banjarmasin
3. Penyidik dan Jaksa Penuntut Umum Kasipisus Kejari Rantau

4. Penyidik dan Jaksa Penuntut Umum Kasipisus Kejari Batulicin.

c. Auditor BPK Perwakilan Kalimantan Selatan.

d. Auditor BPKP wilayah Kalimantan Selatan.

e. Perwakilan tokoh masyarakat di Kalimantan Selatan, yakni LSM Walhi, LSM Gepak, BEM PTN/PTS, dan Advokat.

\section{Alat Pengumpulan Data}

Dalam memperoleh data primer, alat yang digunakan berupa daftar pertanyaan yang disusun secara terstruktur guna memudahkan dalam melakukan wawancara pada informan dan narasumber yang dijadikan responden dalam penelitian ini.

Dalam memperoleh data sekunder, maka alat pengumpulan data yang digunakan berupa dokumen tertulis yang terdiri atas 3 (tiga) bahan hukum, yakni bahan hukum primer, bahan hukum sekunder, dan bahan hukum tersier.

\section{Teknik Pengumpulan Data}

Data primer dikumpulkan dengan teknik wawancara terstruktur dengan berpedoman pada daftar pertanyaan yang 
sudah diolah sesuai dengan objek yang diteliti. Wawancara secara mendalam kepada pihak yang terkait guna memperkuat atau memperjelas data sekunder (bahan hukum) yang telah diperoleh.

Sedangkan data sekunder dihimpun dengan cara melakukan inventarisasi melalui kegiatan studi dokumen atau kepustakaan, yakni kegiatan mengumpulkan dan memeriksa atau menelusuri dokumen-dokumen atau kepustakaan yang dapat memberikan informasi atau keterangan yang berkaitan dengan penelitian ini. Studi dokumen atau pustaka bertujuan untuk menemukan bahan-bahan hukum baik primer, sekunder maupun tersier. Bahan-bahan hukum inilah yang dijadikan patokan atau norma dalam menilai isu hukum yang dipecahkan sebagai masalah hukum.

\section{Teknik Analisis Data}

Analisis data adalah suatu proses dalam menyusun dan memadukan data hasil penelitian kepustakaan dan lapangan agar dapat ditafsirkan (Moleong, 1997 : 190). Proses analisis data dimulai dengan menelaah seluruh data yang tersedia dari berbagai sumber, yaitu wawancara, pengamatan yang sudah dituliskan dalam catatan lapangan, dokumen pribadi, dokumen resmi, dan sebagainya. Data primer dan data sekunder yang sudah terhimpun diolah dan dianalisa secara kualitatif yuridis, sehingga dapat memberikan jawaban atas permasalahan dalam penelitian ini.

\section{Hasil Pembahasan}

1. Kinerja Aparat Penegak Hukum (kepolisian dan kejaksaan) Dalam Penanganan Perkara Tindak Pidana Korupsi di Provinsi Kalimantan Selatan

Kinerja merupakan suatu gambaran mengenai tingkat pencapaian pelaksanaan suatu kegiatan/program/kebijakan dalam mewujudkan sasaran, tujuan, misi, visi serta organisasi. Pada dasarnya pengertian kinerja berkaitan dengan tanggung jawab individu atau organisasi dalam menjalankan apa yang menjadi wewenang dan tanggung jawab yang diberikan kepadanya.

Penegakan hukum adalah proses dilakukannya upaya untuk tegaknya atau berfungsinya norma-norma hukum secara nyata sebagai pedoman perilaku dalam kehidupan bermasyarakat dan 
bernegara. Penegakan hukum merupakan upaya yang dilakukan untuk menjadikan hukum baik dalam arti formil yang sempit maupun dalam arti materiel yang luas, sebagai pedoman perilaku dalam setiap perbuatan hukum, baik oleh para subjek hukum yang bersangkutan maupun oleh aparatur penegakan hukum yang resmi diberi tugas dan kewenangan oleh undangundang untuk menjamin berfungsinya norma-norma hukum yang berlaku dalam kehidupan bermasyarakat dan bernegara.

Aparatur penegak hukum mencakup pengertian mengenai institusi penegak hukum dan aparat (orangnya) penegak hukum. Dalam arti sempit, aparatur penegak hukum yang terlibat dalam proses tegaknya hukum itu, dimulai dari polisi, , jaksa, hakim, penasehat hukum dan petugas sipir pemasyarakatan. Setiap aparat dan aparatur terkait mencakup pula pihak-pihak yang bersangkutan dengan tugas atau perannya yaitu terkait dengan kegiatan penyelidikan, penyidikan, penuntutan, pembuktian, penjatuhan vonis dan pemberian sanksi, serta upaya pemasyarakatan kembali (resosialisasi) terpidana.
Untuk mengetahui berjalannya proses penegakan hukum tindak pidana korupsi di Provinsi Kalimantan Selatan, maka hasil kerja yang telah dicapai oleh aparatur penegak hukum baik Kepolisian dan Kejaksaan di Provinsi Kalimantan Selatan dalam penanganan perkara tindak pidana korupsi perlu dicermati guna mengetahui pencapaian kinerjanya.

\section{a. Kinerja Kepolisian}

Kepolisian Negara Republik Indonesia (POLRI) merupakan bagian dari instansi pemerintahan negara yang menjalankan fungsi di bidang pemeliharaan keamanan dan ketertiban masyarakat, penegakan hukum, perlindungan, pengayoman, dan pelayanan kepada masyarakat, dimana Kepolisian bertujuan agar mewujudkan keamanan dalam negeri yang meliputi terpeliharanya keamanan dan ketertiban masyarakat, tertib dan tegaknya hukum, terselenggaranya perlindungan, pengayoman, dan pelayanan kepada masyarakat, serta terbinanya ketentraman masyarakat dengan menjunjung tinggi hak asasi manusia.

Perkembangan kemajuan masyarakat yang cukup pesat, seiring dengan merebaknya fenomena supremasi hukum, hak asasi manusia, globalisasi, 
demokratisasi, $\quad$ desentralisasi, transparansi, dan akuntabilitas, telah melahirkan berbagai paradigma baru dalam melihat tujuan, tugas, fungsi, wewenang dan tanggung jawab Kepolisian Negara Republik Indonesia yang selanjutnya menyebabkan pula tumbuhnya berbagai tuntutan dan harapan masyarakat terhadap pelaksanaan tugas Kepolisian Negara Republik Indonesia yang makin meningkat dan lebih berorientasi kepada masyarakat yang dilayaninya (Penjelasan Umum UU No 2 Tahun 2002 tentang Kepolisian Negara Republik Indonesia).

Sejak ditetapkannya Perubahan Kedua Undang-Undang Dasar Negara Republik Indonesia Tahun 1945 Bab XII tentang Pertahanan dan Keamanan Negara, Ketetapan MPR RI No. VI/MPR/2000 dan Ketetapan MPR RI No. VII/MPR/2000, maka secara konstitusional telah terjadi perubahan yang menegaskan rumusan tugas, fungsi, dan peran Kepolisian Negara Republik Indonesia serta pemisahan kelembagaan Tentara Nasional Indonesia dan Kepolisian Negara Republik Indonesia sesuai dengan peran dan fungsi masingmasing ( Penjelasan Umum UU No 2
Tahun 2002 tentang Kepolisian Negara Republik Indonesia).

Lahirnya Undang-Undang ini telah didasarkan kepada paradigma baru sehingga diharapkan dapat lebih memantapkan kedudukan dan peranan serta pelaksanaan tugas Kepolisian Negara Republik Indonesia sebagai bagian integral dari reformasi menyeluruh segenap tatanan kehidupan bangsa dan negara dalam mewujudkan masyarakat madani yang adil, makmur, dan beradab berdasarkan Pancasila dan Undang-Undang Dasar Negara Republik Indonesia Tahun 1945 ( Penjelasan Umum UU No 2 Tahun 2002 tentang Kepolisian Negara Republik Indonesia).

Berdasarkan Undang-undang Nomor 2 Tahun 2002 tentang Kepolisian Negara Republik Indonesia Pasal 13 menyatakan bahwa Tugas Pokok Kepolisian Negara Republik Indonesia adalah :

a. memelihara keamanan dan ketertiban masyarakat;

b. menegakkan hukum; dan

c. memberikan perlindungan, pengayoman, dan pelayanan kepada masyarakat.

Sedangkan dalam Pasal 14 ayat (1) dinyatakan bahwa dalam melaksanakan tugas pokok sebagaimana dimaksud 
dalam Pasal 13, Kepolisian Negara

Republik Indonesia bertugas:

a. melaksanakan pengaturan, penjagaan, pengawalan, dan patroli terhadap kegiatan masyarakat dan pemerintah sesuai kebutuhan;

b. menyelenggarakan segala kegiatan dalam menjamin keamanan, ketertiban, dan kelancaran lalu lintas di jalan;

c. membina masyarakat untuk meningkatkan partisipasi masyarakat, kesadaran hukum masyarakat serta ketaatan warga masyarakat terhadap hukum dan peraturan perundang-undangan;

d. turut serta dalam pembinaan hukum nasional;

e. memelihara ketertiban dan menjamin keamanan umum;

f. melakukan koordinasi, pengawasan, dan pembinaan teknis terhadap kepolisian khusus, penyidik pegawai negeri sipil, dan bentuk-bentuk pengamanan swakarsa;

g. melakukan penyelidikan dan penyidikan terhadap semua tindak pidana sesuai dengan hukum acara pidana dan peraturan perundangundangan lainnya; h. menyelenggarakan identifikasi kepolisian, kedokteran kepolisian, laboratorium forensik dan psikologi kepolisian untuk kepentingan tugas kepolisian;

i. melindungi keselamatan jiwa raga, harta benda, masyarakat, dan lingkungan

j. hidup dari gangguan ketertiban dan/atau bencana termasuk memberikan bantuan

k. dan pertolongan dengan menjunjung tinggi hak asasi manusia;

1. melayani kepentingan warga masyarakat untuk sementara sebelum ditangani oleh

m. instansi dan/atau pihak yang berwenang;

n. memberikan pelayanan kepada masyarakat sesuai dengan kepentingannya dalam

o. lingkup tugas kepolisian; serta

p. melaksanakan tugas lain sesuai dengan peraturan perundangundangan.

Terkait dengan Pasal 14 ayat (1) huruf g dimana Kepolisian diberikan kewenangan melakukan penyelidikan dan penyidikan terhadap semua tindak pidana sesuai dengan hukum acara 
Rechtidee, Vol. 11. No. 1, Juni 2016

pidana dan peraturan perundang-

dapat mengganggu ketertiban undangan lainnya, maka dalam hal umum;

pemberantasan tindak pidana korupsi

menjadi salah satu dasar bagi kepolisian dalam melakukan penyelidikan dan penyidikan terhadap perkara korupsi sebagai bagian dari pemberantasan tindak pidana korupsi.

Penjelasan Pasal 14 ayat (1) huruf g dimaksud adalah Ketentuan Undangundang Hukum Acara Pidana memberikan peranan utama kepada Kepolisian Negara Republik Indonesia dalam penyelidikan dan penyidikan sehingga secara umum diberi kewenangan untuk melakukan penyelidikan dan penyidikan terhadap semua tindak pidana. Namun demikian, hal tersebut tetap memperhatikan dan tidak mengurangi kewenangan yang dimiliki oleh penyidik lainnya sesuai dengan peraturan perundang-undangan yang menjadi dasar hukumnya masingmasing.

Kemudian dalam Pasal 15 ayat (1) dinyatakan secara umum kepolisian berwenangan :

c. mencegah dan menanggulangi tumbuhnya penyakit masyarakat;

d. mengawasi aliran yang dapat menimbulkan perpecahan atau mengancam persatuan dan kesatuan bangsa;

e. mengeluarkan peraturan kepolisian dalam lingkup kewenangan administratif kepolisian;

f. melaksanakan pemeriksaan khusus sebagai bagian dari tindakan kepolisian dalam rangka pencegahan;

g. melakukan tindakan pertama di tempat kejadian;

h. mengambil sidik jari dan identitas lainnya serta memotret seseorang;

i. mencari keterangan dan barang bukti;

j. menyelenggarakan Pusat Informasi Kriminal Nasional;

k. mengeluarkan surat izin dan/atau surat keterangan yang diperlukan dalam rangka pelayanan masyarakat;

a. menerima laporan dan/atau pengaduan;

1. memberikan bantuan pengamanan dalam sidang dan pelaksanaan putusan pengadilan, kegiatan 
instansi lain, serta kegiatan masyarakat;

m. menerima dan menyimpan barang temuan untuk sementara waktu.

Berdasarkan hal tersebut dapat dipahami bahwa kepolisian diberikan kewenangan dalam pemberantasan tindak pidana korupsi, selain tindak pidana umum yang terjadi di masyarakat.

Berdasarkan hasil penelitian yang dilakukan berdasarkan persepsi pada praktisi hukum yang ada di Kalimantan Selatan yakni masih lamban dan belum optimalnya dalam penanganan tindak pidana korupsi, dan selama ini kepolisian cenderung menunggu laporan dari masyarakat apabila ada dugaan tindak pidana korupsi, namun sekali lagi masih ada harapan dari para praktisi ini bahwa kepolisian diharapkan akan semakin baik dalam melaksanakan peran dan tugasnya dalam upaya pemberantasan korupsi ini.

Hal ini memang perlu dipahami bahwa kewenangan kepolisian yang terbatas dalam hal melakukan penyelidikan dan penyidikan perkara korupsi, karena adanya proses birokrasi yang harus ditempuh lebih dahulu, sehingga terkadang hal ini dapat menjadi penghambat dalam penanganan tindak pidana korupsi dimaksud.

Ini dapat dilihat dari masih rendahnya penanganan kasus korupsi yang ditangani oleh Dit Reskrimsus Polda Kalsel, Polresta Banjarmasin, Polres Tapin dan Polres Tanah Bumbu selama tahun 2011 sampai dengan 2014 sebagai berikut : 
Tabel 1. Penanganan Perkara Korupsi

Dit Reskrimsus Polda Kalsel, Polresta Banjarmasin, Polres Tapin, dan Polres Tanah Tumbuh

\begin{tabular}{|c|c|c|c|c|c|c|c|c|c|}
\hline \multirow[t]{6}{*}{ No } & \multirow[t]{6}{*}{ Th. } & \multirow{2}{*}{\multicolumn{4}{|c|}{ Jumlah Perkara }} & \multicolumn{4}{|c|}{ Rata-rata Lamanya Proses } \\
\hline & & & & & & \multicolumn{4}{|c|}{ Keterangan } \\
\hline & & Dit & Polresta & Polres & Polres & & Polresta & Polres & Polres \\
\hline & & Reskrimsus & Bjrm & Tapin & Tanah & Reskrimsus & Bjrm & Tapin & Tanah \\
\hline & & Polda & & & Tumbuh & Polda & & & Tumbuh \\
\hline & & Kalsel & & & & Kalsel & & & \\
\hline \multirow[t]{2}{*}{1.} & \multirow[t]{2}{*}{2011} & \multirow[t]{2}{*}{4} & \multirow[t]{2}{*}{ - } & \multirow[t]{2}{*}{1} & \multirow[t]{2}{*}{-} & 3 thn & - & 8 bln & - \\
\hline & & & & & & $\begin{array}{l}\mathrm{P} 21,2 \\
\text { kasus }\end{array}$ & & P 21 & \\
\hline \multirow[t]{2}{*}{2.} & \multirow[t]{2}{*}{2012} & \multirow[t]{2}{*}{8} & \multirow[t]{2}{*}{1} & \multirow[t]{2}{*}{1} & \multirow[t]{2}{*}{1} & 4 bln- 1 thn & 7 bln & 6 bln & 1 thn \\
\hline & & & & & & $\begin{array}{l}\mathrm{P} 21,7 \\
\text { kasus }\end{array}$ & P 21 & P 21 & \\
\hline \multirow[t]{2}{*}{3.} & \multirow[t]{2}{*}{2013} & \multirow[t]{2}{*}{13} & \multirow[t]{2}{*}{3} & \multirow[t]{2}{*}{1} & \multirow[t]{2}{*}{1} & $\begin{array}{c}11 \text { bln }-1 \\
\text { thn }\end{array}$ & $\begin{array}{c}1 \text { thn } 4 \\
\text { bln }\end{array}$ & 7 bln & 1 thn \\
\hline & & & & & & $\begin{array}{l}\text { P 21, } 8 \\
\text { Kasus }\end{array}$ & $\begin{array}{l}\text { P 21, } 2 \\
\text { kasus }\end{array}$ & $\mathrm{P} 21$ & \\
\hline \multirow[t]{2}{*}{4.} & \multirow[t]{2}{*}{2014} & \multirow[t]{2}{*}{4} & \multirow[t]{2}{*}{2} & \multirow[t]{2}{*}{2} & \multirow[t]{2}{*}{1} & - & - & - & 1 thn \\
\hline & & & & & & SPDP & SIDIK & SIDIK & \\
\hline
\end{tabular}

Sumber : Penelitian 2014

Karena hal itulah maka kiranya penanganan korupsi oleh pihak kepolisian kiranya dapat menjadi perhatian, disamping memang dalam menjalannya tugasnya tentu saja harus mendapatkan dukungan dari instansi terkait lainnya.

\section{b. Kinerja Kejaksaan}

Kejaksaan Republik Indonesia adalah termasuk salah satu badan yang fungsinya berkaitan dengankekuasaan kehakiman menurut Undang-Undang Dasar Negara Republik Indonesia Tahun 1945. 
Dimana Undang-Undang Dasar Negara Republik Indonesia Tahun 1945 menentukan secara tegas bahwa negara Indonesia adalah negara hukum. Sejalan dengan ketentuan tersebut maka salah satu prinsip penting negara hukum adalah adanya jaminan kesederajatan bagi setiap orang dihadapan hukum (equality before the law). Oleh karena itu setiap orang berhak atas pengakuan, jaminan, perlindungan, dan kepastian hukum yang adil, serta perlakuan yang sama dihadapan hukum ( Penjelasan UU No 16 Tahun 2014 tentang Kejaksaan Republik Indonesia).

Dalam usaha memperkuat prinsip di atas maka salah satu substansi penting perubahan Undang-UndangDasar Negara Republik Indonesia Tahun 1945 telah membawa perubahan yang mendasar dalamkehidupan ketatanegaraan khususnya dalam pelaksanaan kekuasaan kehakiman. Berdasarkanperubahan tersebut ditegaskan bahwa ketentuan badanbadan lain yang fungsinya berkaitan dengankekuasaan kehakiman diatur dalam undang-undang. Ketentuan badanbandan lain tersebut dipertegasoleh Undang-Undang Nomor 4 Tahun 2004 tentang Kekuasaan Kehakiman yang menyatakan bahwabadan-badan lain yang fungsinya berkaitan dengan kekuasaan kehakiman, salah satunya adalahKejaksaan Republik Indonesia (Penjelasan UU No 16 Tahun 2014 tentang Kejaksaan Republik Indonesia).

Dalam melaksanakan fungsi, tugas, dan wewenangnya, Kejaksaan Republik Indonesia sebagailembaga pemerintahan yang melaksanakan kekuasaan negara di bidang penuntutan harus mampumewujudkan kepastian hukum, ketertiban hukum, keadilan dan kebenaran berdasarkan hukum danmengindahkan norma-norma keagamaan, kesopanan, dan kesusilaan, serta wajib menggali nilainilaikemanusiaan, hukum dan keadilan yang hidup dalam masyarakat ( Penjelasan UU No 16 Tahun 2014 tentang Kejaksaan Republik Indonesia).

Kejaksaan juga harus mampu terlibat sepenuhnya dalam proses pembangunan antara lain turutmenciptakan kondisi yang mendukung dan mengamankan pelaksanaan pembangunan untukmewujudkan masyarakat adil dan makmur berdasarkan Pancasila, serta berkewajiban untuk turutmenjaga dan menegakkan kewibawaan pemerintah dan negara serta melindungi 
kepentinganmasyarakat (Penjelasan UU No 16 Tahun 2014 tentang Kejaksaan Republik Indonesia).

Berdasarkan Pasal 2 ayat (1) Undang-Undang Nomor 16 Tahun 2004 tentang Kejaksaan Republik Indonesia, dinyatakan adalah lembaga pemerintahan yang melaksanakan kekuasaan negara di bidang penuntutan serta kewenangan lain berdasarkan undang-undang.

Sebagai badan yang berwenang dalam penegakan hukum dan keadilan, Kejaksaan dipimpin oleh Jaksa Agung yang dipilih oleh dan bertanggung jawab kepada Presiden. Kejaksaan Agung, Kejaksaan Tinggi, dan Kejaksaan Negeri merupakan kekuasaan negara khususnya di bidang penuntutan (Pasal 3 ayat (1) UU No 16 Tahun 2004 tentang Kejaksaan Republik Indonesia). Dimana semuanya merupakan satu kesatuan yang utuh yang tidak dapat dipisahkan (en een ondelbaar) (Pasal 2 ayat (3) UU No 16 Tahun 2004 tentang Kejaksaan Republik Indonesia).

Mengacu pada Undang-Undang Nomor 16 Tahun 2004 tentang Kejaksaan Republik Indonesia, Kejaksaan sebagai salah satu lembaga penegak hukum dituntut untuk lebih berperan dalam menegakkan supremasi hukum, perlindungan kepentingan umum, penegakan hak asasi manusia, serta pemberantasan Korupsi, Kolusi, dan Nepotisme (KKN). Dalam melaksanakan kekuasaan negara di bidang penuntutan harus melaksanakan fungsi, tugas, dan wewenangnya secara merdeka, terlepas dari pengaruh kekuasaan pemerintah dan pengaruh kekuasaan lainnya

http://minsatu.blogspot.com, diakses tanggal 16 Agustus 2014).

Dalam menjalankan tugas dan wewenangnya, Kejaksaan berada pada posisi sentral dengan peran strategis dalam pemantapan ketahanan bangsa. Karena Kejaksaan berada di poros dan menjadi filter antara proses penyidikan dan proses pemeriksaan di persidangan serta juga sebagai pelaksana penetapan dan putusan pengadilan. Dengan begitu Kejaksaan sebagai pengendali proses perkara (dominus litis), karena hanya institusi Kejaksaan yang dapat menentukan apakah suatu kasus/perkara dapat diajukan ke Pengadilan atau tidak berdasarkan alat bukti yang sah menurut Hukum Acara Pidana http://minsatu.blogspot.com, diakses tanggal 16 Agustus 2014). 
Berdasarkan Pasal 30 ayat (1) UU No 16 Tahun 2004, selain dari melakukan penuntutan, melaksanakan penetapan hakim dan putusan pengadilan yang telah memperoleh kekuatan hukum tetap (executive ambtenaar). Kejaksaan juga memiliki tugas dan wewenang dalam bidang pidana lainnya yakni melakukan pengawasan terhadap pelaksanaan putusan pidana bersyarat, putusan pidana pengawasan, dan keputusan lepas bersyarat; melakukan penyelidikan terhadap tindak pidana tertentu berdasarkan undang-undang; melengkapi berkas perkara tertentu dan untuk itu dapat melakukan pemeriksaan tambahan sebelum dilimpahkan ke pengadilan yang dalam pelaksanaannya dikoordinasikan dengan penyidik.

Dalam bidang perdata dan tata usaha negara, kejaksaan dengan kuasa khusus dapat bertindak baik di dalam maupun di luar pengadilan untuk dan atas nama negara atau pemerintah, adapun yang dapat dilakukan jaksa dalam bidang ini antara lain melakukan penegakan hukum; bantuan hukum sebagai jaksa pengacara negara; melakukan pelayanan hukum kepada masyarakat; memberikan pertimbangan hukum kepada lembaga pemerintah; dan melakukan tindakan hukum lain. Sedang dalam bidang ketertiban dan ketenteraman umum, kejaksaan turut menyelenggarakan kegiatan peningkatan kesadaran hukum masyarakat; pengamanan kebijakan penegakan hukum; pengawasan peredaran barang cetakan; pengawasan aliran kepercayaan yang dapat membahayakan masyarakat dan negara; pencegahan penyalahgunaan dan/atau penodaan agama; penelitian dan pengembangan hukum serta statistik criminal ( http://minsatu.blogspot.com, diakses tanggal 16 Agustus 2014).

Pasal 1 butir 1 Undang-undang Nomor 16 Tahun 2004 tentang kejaksaan Republik Indonesia, menyebutkan bahwa jaksa adalah pejabat fungsional yang diberi wewenang oleh Undangundang ini untuk bertindak sebagai penuntut umum dan pelaksana putusan pengadilan yang telah memperoleh kekuatan hukum serta wewenang lain berdasarkan undang-undang.

Sedangkan dalam Pasal 1 butir 2 Undang-undang tersebut disebutkan bahwa Penuntut Umum adalah Jaksa yang diberi wewenang oleh Undangundang ini untuk melakukan penuntutan dan melaksanakan penetapan hakim. 
Hal tersebut juga di atur dalam Undang-undang Nomor 8 Tahun 1981 tentang Hukum Acara Pidana yang kerap disebut dengan KUHAP yakni dalam Pasal 1 butir 6 huruf a dan b Jo. Pasal 13 dengan begitu telah jelas bahwa penuntut umum sudah pasti adalah seorang jaksa, sedangkan jaksa belum tentu seorang penuntut umum. Bila melihat uraian di atas, dapat dikatakan bahwa peran jaksa selaku penuntut umum dalam penegakan hukum tentu berada dalam koridor tindakan penuntutan.

Adapun dalam rangka persiapan tindakan penuntutan atau kerap dikenal dengan tahap Pra Penuntutan, dapat diperinci mengenai tugas dan wewenang dari Jaksa Penuntut Umum sebagai berikut antara lain : (http://minsatu.blogspot.com, diakses tanggal 16 Agustus 2014).

a. Berdasarkan Pasal 109 ayat (1) KUHAP, jaksa menerima pemberitahuan dari penyidik atau penyidik PNS dan penyidik pembantu dalam hal telah dimulai penyidikan atas suatu peristiwa yang merupakan tindak pidana yang biasa disebut dengan SPDP (Surat Pemberitahuan Dimulainya Penyidikan). b. Berdasarkan pasal 110 ayat (1) KUHAP, penyidik dalam hal telah selesai melakukan penyidikan, penyidik wajib segera menyerahkan berkas perkara pada penuntut umum. Selanjutnya apabila dihubungkan dengan ketentuan Pasal 138 ayat (1) KUHAP penuntut umum segera mempelajari dan meneliti berkas perkara tersebut yakni:

1. Mempelajari adalah apakah tindak pidana yang disangkakan kepada tersangka telah memenuhi unsur-unsur dan telah memenuhi syarat pembuktian. Jadi yang diperiksa adalah materi perkaranya.

2. Meneliti adalah apakah semua persyaratan formal telah dipenuhi oleh penyidik dalam membuat berkas perkara, yang antara lain perihal identitas tersangka, locus dan tempus tindak pidana serta kelengkapan administrasi semua tindakan yang dilakukan oleh penyidik pada saat penyidikan.

c. Mengadakan Prapenuntutan sesuai pasal 14 huruf b KUHAP dengan memperhatikan ketentuan Pasal 110 
ayat (3) dan (4) serta ketentuan Pasal 138 ayat (1) dan (2) KUHAP. Apabila penuntut umum berpendapat bahwa hasil penyidikan kurang lengkap (P-18), penuntut umum segera mengembalikan berkas perkara itu kepada penyidik disertai petunjuk untuk dilengkapi (P-19). Dalam hal ini penyidik wajib segera melakukan penyidikan tambahan sebagaimana petunjuk penuntut umum tersebut sesuai Pasal 110 ayat (2) dan (3) KUHAP.

d. Bila berkas perkara telah dilengkapi sebagaimana petunjuk, maka menurut ketentuan Pasal 139 KUHAP, penuntut umum segera menentukan sikap apakah suatu berkas perkara tersebut telah memenuhi persyaratan atau tidak untuk dilimpahkan ke pengadilan (P-21).

e. Mengadakan tindakan lain dalam lingkup tugas dan tanggung jawab selaku penuntut umum sesuai Pasal 14 huruf I KUHAP. Menurut Penjelasan pasal tersebut yang dimaksud dengan "tindakan lain" adalah antara lain meneliti identitas tersangka, barang bukti dengan melihat secara tegas batas wewenang dan fungsi antara penyidik, penuntut umum dan pengadilan.

f. Berdasarkan Pasal 140 ayat (1) KUHAP, penuntut umum berpendapat bahwa dari hasil penyelidikan dapat dilakukan penuntutan, maka penuntutan umum secepatnya membuat surat dakwaan untuk segera melimpahkan perkara tersebut ke pengadilan untuk diadili.

g. Berdasarkan Pasal 8 ayat (3) huruf b KUHAP, penuntut umum menerima penyerahan tanggung jawab atas berkas perkara, tersangka serta barang bukti. Bahwa proses serah terima tanggung jawab tersangka disini sering disebut Tahap 2, dimana di dalamnya penuntut umum melakukan pemeriksaan terhadap tersangka baik identitas maupun tindak pidana yang dilakukan oleh tersangka, dapat melakukan penahanan/penahanan lanjutan terhadap tesangka sebagaimana Pasal 20 ayat (2) KUHAP dan dapat pula melakukan penangguhan penahanan serta dapat mencabutnya kembali. 
Sedangkan tugas dan wewenang Jaksa Penuntut Umum dalam poses penuntutan antara lain adalah sebagai berikut : ( http://minsatu.blogspot.com, diakses tanggal 16 Agustus 2014).

a. Berdasarkan Pasal 143 ayat (1) KUHAP penuntut umum melimpahkan perkara ke Pengadilan Negeri dengan permintaan agar segera mengadili perkara tersebut disertai dengan surat dakwaan.

b. Melakukan pembuktian atas surat dakwaan yang dibuat, yakni dengan alat bukti yang sah sebagaimana Pasal 184 ayat (1) KUHAP, dalam hal itu penuntut umum berkewajiban menghadirkan terdakwa berikut saksi-saksi, ahli serta barang bukti di depan persidangan untuk dilakukan pemeriksaan.

c. Berdasarkan Pasal 182 ayat (1) huruf a, setelah pemeriksaan dinyatakan selesai penuntut umum Mengajukan tuntutan pidana, meskipun sebenarnya yang lebih tepat yang diajukan adalah tuntutan (requisitoir),karena tidak menutup peluang selain dari tuntutan pidana atas diri terdakwa, penuntut umum dapat menuntut bebas diri terdakwa. d. Bahwa bila atas tuntutan terhadap terdakwa dan berdasarkan alat bukti yang sah majelis hakim berkeyakinan bahwa suatu tindak pidana benar-benar terjadi dan terdakwalah yang bersalah melakukannya, maka majelis hakim menjatuhkan putusan, dimana bila terdakwa dan penuntut umum kemudian menerima, putusan tersebut kemudian berkekuatan hukum tetap (inkracht), maka berdasarkan Pasal 270 KUHAP, jaksa melaksanakan putusan (eksekusi) tersebut.

e. Terkait poin $d$ tersebut di atas, apabila terdakwa maupun penuntut umum tidak menerima putusan tersebut maka terdakwa maupun penuntut umum dapat melakukan upaya hukum, upaya hukum banding berdasarkan Pasal 233 KUHAP, dan/atau upaya hukum kasasi berdasarkan Pasal 244 KUHAP.

f. Bahwa selain hal tersebut, berdasarkan Pasal 140 ayat (2) KUHAP, penuntut umum dapat memutuskan untuk menghentikan penuntutan dengan mengelarkan SKPP (Surat Ketetapan Peghentian 
Penuntutan) dikarenakan alasan bahwa perkara tersebut tidak terdapat cukup bukti, peristiwanya bukan merupakan tindak pidana atau perkara ditutup demi hukum, SKPP tersebut diberitahukan kepada tersangka dan apabila ditahan tersangka harus segera dikeluarkan. Turunan surat tersebut wajib disampaikan kepada tersangka atau keluarganya, penasehat hukum, pejabat RUTAN, penyidik dan hakim. Bila kemudian ditemukan alasan baru, penuntut umum dapat menuntut tersangka, alasan baru tersebut adalah novum (bukti baru).

Bahwa dalam Pasal 35 Undangundang tentang Kejaksaan, selain tindakan-tindakan tersebut, Jaksa Agung secara khusus mempunyai tugas dan wewenang menetapkan serta mengendalikan kebijakan penegakan hukum dan keadilan dalam ruang lingkup tugas dan wewenang kejaksaan; mengefektifkan proses penegakan hukum yang diberikan oleh undangundang; mengesampingkan perkara demi kepentingan umum; mengajukan kasasi demi kepentingan hukum kepada Mahkamah Agung dalam perkara pidana, perdata, dan tata usaha negara
Bila melihat uraian yang telah digambarkan di atas, semua tindakantindakan yang dilakukan oleh jaksa penuntut umum baik dalam proses pra penuntutan maupun penuntutan sesungguhnya dilakukan atas dasar keadilan dan kebenaran berdasarkan Ketuhanan Yang Maha Esa berdasarkan pada Pasal 8 ayat (3) Undang-undang Kejaksaan.

Penegakan hukum demi keadilan tersebut tentu juga mencakup adil bagi terdakwa, adil bagi masyarakat yang terkena dampak akibat perbuatan terdakwa dan adil di mata hukum, dengan begitu dengan sendirinya apa yang dilakukan oleh jaksa penuntut umum dalam rangka penegakan hukum adalah untuk mencapai tujuan hukum yakni kepastian hukum, menjembatani rasa keadilan dan kemanfaatan hukum bagi para pencari keadilan ( http://minsatu.blogspot.com, diakses tanggal 16 Agustus 2014).

Dari sinilah maka dapat dikatakan bahwa kejaksaan adalah sebuah lembaga dimana supremasi hukum ditegakkan, mengingat lembaga ini adalah pelaksana dari putusan pengadilan. Lembaga inilah yang memberikan perlindungan terhadap kepentingan umum dan dapat dikatakan 
bahwa kejaksaan adalah tempat dimana hak asasi manusia diperjuangkan dan ditegakkan.

Data penanganan perkara korupsi yang ditangani oleh KejaksaanTinggi
Kalimantan Selatan, Kejaksaan Negeri Banjarmasin, Kejaksaan Negeri Rantau dan Kejaksaan Negeri Tanah Bumbu, gai berikut:

\section{Tabel 2. Penanganan Perkara Korupsi}

Kejaksaan Tinggi Kalimantan Selatan, Kejaksaan Negeri Banjarmasin, Kejaksaan Negeri Rantau, Kejaksaan Negeri Tanah Tumbuh

\begin{tabular}{cccccccccc}
\hline No. & Th. & \multicolumn{3}{c}{ Jumlah Perkara } & \multicolumn{4}{c}{ Rata-rata Lamanya Proses } \\
\hline & & Kejati & Kejari & Kejari & Kejari & Kejati & Kejari & Kejari & Kejari \\
& & Kalsel & Bjrm & Rantau & $\begin{array}{c}\text { Tanah } \\
\text { Tumbuh }\end{array}$ & Kalsel & Bjrm & Rantau & Tanah \\
& & & & & & & & Tumbuh \\
\hline 1. & 2011 & - & - & - & - & - & - & - & - \\
\hline 2. & 2012 & 2 & - & 2 & - & 1 & - & 1 thn & - \\
\hline 3. & 2013 & 5 & - & 5 & - & 1 & - & 1 thn & - \\
\hline 4. & 2014 & 3 & - & 2 & - & - & - & - & - \\
\hline
\end{tabular}

Sumber : Penelitian 2014.

\section{c. Peran Lembaga Terkait dalam} Penanganan Tindak Pidana Korupsi

\section{Peran Badan Pemeriksa Keuangan dalam Pemberantasan Korupsi}

Undang-undang Dasar Negara Republik Indonesia Tahun 1945 telah mengalami perubahan yang mendasar diantaranya pasal 23 mengenai kedudukan dan tugas Badan Pemeriksaan Keuangan. Para pembentuk Undang-Undang Republik Indonesia 1945 menyadari bahwa pemeriksaan pengelolaan dan tanggung jawab Pemerintah tentang keuangan negara merupakan kewajiban yang berat, sehingga perlu dibentuk suatu BadanPemeriksaan Keuangan yang terlepas dari pengaruh dan kekuasaan pemerintah.

Badan Pemeriksa Keuangan, yang selanjutnya disingkat BPK, adalah lembaga negara yang bertugas untuk memeriksa pengelolaan dan tanggung jawab keuangan negara sebagaimana 
dimaksud dalam Undang-Undang Dasar Negara Republik Indonesia Tahun 1945.

Perubahan ketiga UUD 45 merupakan salah satu reformasi atas ketentuan Pasal 23 ayat (5) tentang Badan Pemeriksaan Keuangan. Bab tentang Badan Pemeriksaan Keuangan adalah bab baru. Sebelumnya Badan Pemeriksaan Keuangan diatur dalam satu ayat, yakni dalam Pasal 23 ayat (5) UUD 1945 “ Untuk memeriksa keuangan negara diadakan suatu Badan Pemeriksaan Keuangan, yang peraturannya ditetapkan dengan undang-undang. Hasil pemeriksaan itu diberitahukan kepada Dewan Pewakilan Rakyat". Perubahan UUD 1945 menjadi tiga pasal yaitu, Pasal 23E, Pasal 23F, Pasal 23G.

Dipisahkanya BPK dalam bab tersendiri ( $\mathrm{BAB}$ VIIIA), yang sebelumnya merupakan bagian dari $\mathrm{BAB}$ VIII tentang Hal Keuangan dimaksudkan untuk memberikan dasar hukum yang kuat serta pengaturan rinci mengenai BPK yang bebas dan mandiri. Dalam kedudukannya sebagai pemeriksa keuangan negara dan APBD, serta untuk dapat menjangkau pemeriksaan di daerah, BPK membuka kantor di setiap provinsi.

\section{Badan Pemeriksa Keuangan} Indonesia memiliki wewenang BPK yang berlaku, wewenangnya yaitu:

a. Menentukan menentukan objek pemeriksaan, merencanakan dan melaksanakan pemeriksaan, menentukan waktu dan metode pemeriksaan serta menyusun dan menyajikan laporan pemeriksaan.

b. Meminta keterangan dan/atau dokumen yang wajib diberikan oleh setiap orang, unit organisasi Pemerintah Pusat, Pemerintah Daerah, Lembaga Negara lainnya, Bank Indonesia, Badan Usaha Milik Negara, Badan Layanan Umum, Badan Usaha Milik Daerah, dan lembaga atau badan lain yang mengelola keuangan negara.

c. Melakukan pemeriksaan di tempat periyimpanan uang dan barang milik negara, di tempat pelaksanaan kegiatan, pembukuan dan tata usaha keuangan negara, serta pemeriksaan terhadap perhitungan-perhitungan, surat-surat, bukti-bukti, rekening koran, pertanggungjawaban, dan daftar lainnya yang berkaitan dengan pengelolaan keuangan negara. 
d. Menetapkan jenis dokumen, data, serta informasi mengenai pengelolaan dan tanggung jawab keuangan negara yang wajib disampaikan kepada BPK.

e. Menetapkan standar pemeriksaan keuangan negara setelah konsultasi dengan

Pemerintah

Pusat/Pemerintah Daerah yang wajib digunakan dalam pemeriksaan pengelolaan dan tanggung jawab keuangan negara.

f. Menetapkan kode etik pemeriksaan pengelolaan dan tanggung jawab keuangan negara.

g. Menggunakan tenaga ahli dan/ atau tenaga pemeriksa di luar BPK yang bekerja untuk dan atas nama BPK.

h. Membina jabatan fungsional Pemeriksa.

i. Memberi pertimbangan atas Standar Akuntansi Pemerintahan.

j. Memberi pertimbangan atas rancangan sistem pengendalian intern Pemerintah Pusat/Pemerintah Daerah sebelum ditetapkan oleh Pemerintah Pusat/Pemerintah Daerah.

Terkait dengan peran BPK Perwakilan Kalimantan Selatan, hanya berperan memeriksa APBD (Anggaran
Pendapatan dan Belanja Daerah) dan BUMD (Badan Usaha Milik Daerah) saja, selebihnya kewenangan pemeriksaan berada pada BPK Pusat.

Namun dalam hal pemberantasan korupsi BPK mempunyai beberapa kesepakatan bersama dengan beberapa lembaga terkait, yang dituangkan dalam MoU sebagai berikut :

1. Badan Pemeriksa Keuangan Republik Indonesia dengan Komisi Pemberantasan Tindak Pidana Korupsi tentang Kerjasama Dalam Upaya Pencegahan dan Pemberantasan Tindak Pidana Korupsi.

2. Badan Pemeriksa Keuangan Republik Indonesia denganPusat Pelaporan dan Analisis Transaksi Keuangan tentang Kerjasama Dalam Rangka Pencegahan dan Pemerantasan Tidak Pidana Pencucian Uang.

3. Badan Pemeriksa Keuangan Republik Indonesia dengan Kejaksaan Agung Republik Indonesia tentang Tindak Pidana Lanjut Penegakan Hukum Terhadap Hasil Pemeriksaan BPK yang Diduga Mengandung Unsur Tindak Pidana. 


\section{Peran Badan Pengawasan Keuangan dan Pembangunan dalam Pemberantasan Korupsi.}

Sesuai dengan Pasal 52, 53 dan 54 Keputusan Presiden Republik Indonesia Nomor 103 Tahun 2001 Tentang Kedudukan, Tugas, Fungsi, Kewenangan, Susunan Organisasi, Dan Tata Kerja Lembaga Pemerintah Non Departemen, BPKP mempunyai tugas melaksanakan tugas Pemerintahan di bidang pengawasan keuangan dan pembangunan sesuai dengan ketentuan peraturan perundang-undangan yang berlaku.

Badan Pengawasan Keuangan dan Pembangunan, atau yang disingkat BPKP, adalahLembaga pemerintah nonkementerianIndonesia yang melaksanakan tugas pemerintahan di bidang pengawasan keuangan dan pembangunan yang berupa Audit, Konsultasi, Asistensi, Evaluasi, Pemberantasan KKN serta Pendidikan dan Pelatihan Pengawasan sesuai dengan peraturan yang berlaku.

Hasil pengawasan keuangan dan pembangunan dilaporkan kepada Presiden selaku kepala pemerintahan sebagai bahan pertimbangan untuk menetapkan kebijakan-kebijakan dalam menjalankan pemerintahan dan memenuhi kewajiban akuntabilitasnya. Hasil pengawasan BPKP juga diperlukan oleh para penyelenggara pemerintahan lainnya termasuk pemerintah provinsi dan kabupaten/kota dalam pencapaian dan peningkatan kinerja instansi yang dipimpinnya.

Dalam melaksanakan tugas, BPKP menyelenggarakan fungsi :

a. pengkajian dan penyusunan kebijakan nasional di bidang pengawasan keuangan dan pembangunan;

b. perumusan dan pelaksanaan kebijakan di bidang pengawasan keuangan dan pembangunan;

c. koordinasi kegiatan fungsional dalam pelaksanaan tugas BPKP;

d. pemantauan, pemberian bimbingan dan pembinaan terhadap kegiatan pengawasan keuangan dan pembangunan;

e. penyelenggaraan pembinaan dan pelayanan administrasi umum di bidang perencanaan umum, ketatausahaan, organisasi dan tatalaksana, kepegawaian, keuangan, kearsipan, hukum, persandian, perlengkapan dan rumah tangga. 
Dalam menyelenggarakan fungsi tersebut, BPKP mempunyai kewenangan

a. penyusunan rencana nasional secara makro di bidangnya;

b. perumusan kebijakan di bidangnya untuk mendukung pembangunan secara makro;

c. penetapan sistem informasi di bidangnya;

d. pembinaan dan pengawasan atas penyelenggaraan otonomi daerah yang meliputi pemberian pedoman, bimbingan, pelatihan, arahan, dan supervisi di bidangnya;

e. penetapan persyaratan akreditasi lembaga pendidikan dan sertifikasi tenaga profesional/ahli serta persyaratan jabatan di bidangnya;

f. kewenangan lain sesuai dengan ketentuan peraturan perundangundangan yang berlaku, yaitu :

1. memasuki semua kantor, bengkel, gudang, bangunan, tempat-tempat penimbunan, dan sebagainya;

2. meneliti semua catatan, data elektronik, dokumen, buku perhitungan, surat-surat bukti, notulen rapat panitia dan sejenisnya, hasil survei laporan- laporan pengelolaan, dan suratsurat lainnya yang diperlukan dalam pengawasan;

3. pengawasan kas, surat-surat berharga, gudang persediaan dan lain-lain;

4. meminta keterangan tentang tindak lanjut hasil pengawasan, baik hasil pengawasan BPKP sendiri maupun hasil pengawasan Badan Pemeriksa Keuangan, dan lembaga pengawasan lainnya.

Pendekatan yang dilakukan BPKP diarahkan lebih bersifat preventif atau pembinaan dan tidak sepenuhnya audit atau represif. Kegiatan sosialisasi, asistensi atau pendampingan, dan evaluasi merupakan kegiatan yang mulai digeluti BPKP. Sedangkan audit investigatif dilakukan dalam membantu aparat penegak hukum untuk menghitung kerugian keuangan negara.

Pada masa reformasi ini BPKP banyak mengadakan Memorandum of Understanding (MoU) atau Nota Kesepahaman dengan pemda dan kementerian/lembaga sebagai mitra kerja BPKP (Metode yang umum dilakukan oleh kartel ekonomi). MoU tersebut pada umumnya membantu mitra kerja untuk 
meningkatkan kinerjanya dalam rangka mencapai good governance.

Terkait dengan hal ini BPKP Perwakilan Kalimantan Selatan memiliki nota kesepakatan antara Kejaksaan Tinggi Kalimantan Selatan, Kepolisian Daerah Kalimantan Selatan dan Perwakilan Badan Pengawasan Keuangan dan Pembangunan Provinsi Kalimantan Selatan tentang Kerjasama Dalam Penanganan Kasus Penyimpangan Pengelolaan Keuangan Negara Yang Berindikasi Tindak Pidana Korupsi Termasuk Dana Nonbudgeter.

BPKP menegaskan tugas pokoknya pada pengembangan fungsi preventif. Hasil pengawasan preventif (pencegahan) dijadikan model sistem manajemen dalam rangka kegiatan yang bersifat pre-emptive. Apabila setelah hasil pengawasan preventif dianalisis terdapat indikasi perlunya audit yang mendalam, dilakukan pengawasan represif non justisia. Pengawasan represif non justisia digunakan sebagai dasar untuk membangun sistem manajemen pemerintah yang lebih baik untuk mencegah moral hazard atau potensi penyimpangan (fraud). Tugas perbantuan kepada penyidik POLRI, Kejaksaan dan KPK, sebagai amanah untuk menuntaskan penanganan TPK guna memberikan efek deterrent represif justisia, sehingga juga sebagai fungsi pengawalan atas kerugian keuangan negara untuk dapat mengoptimalkan pengembalian keuangan negara.

Dalam melaksanakan tugasnya, BPKP hanya didukung oleh peraturan presiden non Undang - undang yaitu :

1. Keputusan Presiden RI No.103 Tahun 2001 tentang Kedudukan, Tugas Fungsi, Kewenangan, Susunan Organisasi dan Tata Kerja Lembaga Pemerintah Non Departemen yang telah diubah terakhir dengan Peraturan Presiden Republik Indonesia Nomor 64 Tahun 2005

2. Peraturan Pemerintah No. 60 Tahun 2008 tentang Sistem Pengendalian Internal Pemerintah

3. Instruksi Presiden No.4 Tahun 2011 tanggal 17 Februari 2011 tentang Percepatan Peningkatan Kualitas Akuntabilitas Keuangan Negara

\section{Persepsi Masyarakat terhadap Kinerja Penegak Hukum Dalam Penanganan Perkara Tindak Pidana Korupsi}


Tidak dapat dipungkiri bahwa penegakan hukum merupakan indikator yang sangat penting untuk mengukur tingkat keberhasilan pembangunan hukum suatu negara. Baik buruknya penegakan hukum akan berpengaruh terhadap tingkat persepsi masyarakat terhadap supremasi hukum, termasuk didalamnya penegakan hukum tindak pidana korupsi.
Untuk mengetahui kinerja penegak hukum (Kepolisian dan Kejaksaan) dalam penanganan perkara tindak pidana korupsi di Provinsi Kalimantan Selatan, perlu diketahui pula persepsi masyarakat terhadap kinerja dimaksud.

Berdasarkan hasil penelitian atas persepsi masyarakat Kalimantan Selatan diperoleh hasil sebagaimana dapat dilihat pada tabel-tabel berikut ini:

Tabel 3. Usia Responden

\begin{tabular}{lllc}
\hline No & Usia & Frekuensi & Persentase \\
\hline 1 & Di bawah 50 Tahun & 23 & $57,5 \%$ \\
\hline 2 & Di atas 50 Tahun & 17 & $42,5 \%$ \\
\hline & JUMLAH & 40 & $100 \%$ \\
\hline
\end{tabular}

Sumber : Hasil Penelitian, 2014

Dalam penelitian ini yang menjadi sampel penelitian adalah sebanyak 40 orang responden yang tersebar pada 2 kabupaten dan 1 kota di wilayah Provinsi Kalimantan Selatan yang dijadikan sebagai obyek penelitian, yakni terdiri atas $57,5 \%$ responden berada di bawah usia 50 tahun dan $42,5 \%$ responden berada diusia di atas 50 tahun.

\section{Tabel 4. Jenis Kelamin Responden}

\begin{tabular}{|l|l|l|c|}
\hline No & Jenis Kelamin & Frekuensi & Persentase \\
\hline 1 & Laki-laki & 26 & $65 \%$ \\
\hline 2 & Perempuan & 14 & $35 \%$ \\
\hline & JUMLAH & 40 & $100 \%$ \\
\hline
\end{tabular}

Sumber : Hasil Penelitian, 2014

Hasil penelitian menunjukkan bahwa berdasarkan pada jenis kelamin, terdapat
$65 \%$ responden berjenis kelamin lakilaki dan $35 \%$ responden berjenis kelamin perempuan. 
Tabel 5. Pendidikan Responden

\begin{tabular}{llcc}
\hline No & Pendidikan & Frekuensi & Persentase \\
\hline 1 & SD/sederajat & 0 & $0 \%$ \\
\hline 2 & SMP/sederajat & 0 & $0 \%$ \\
\hline 3 & SMA/sederajat & 19 & $47,5 \%$ \\
\hline 4 & S 1/Sederajat & 15 & $37,5 \%$ \\
\hline 5 & S 2/Sederajat & 4 & $10 \%$ \\
\hline 6 & S 3/Sederajat & 2 & $5 \%$ \\
\hline & JUMLAH & 40 & $100 \%$
\end{tabular}

Sumber : Hasil Penelitian, 2014

Hasil penelitian menunjukkan bahwa berdasarkan pada tingkat pendidikan, terdapat $\quad 47,5 \quad \% \quad$ responden berpendidikan SMA/sederajat, $37,5 \%$ responden berpendidikan S 1/sederajat, $10 \%$ responden berpendidikan $\mathrm{S}$ 2/sederajat, dan $5 \%$ responden berpendidikan S 3/sederajat.

Tabel 6.

Pekerjaan Responden

\begin{tabular}{lllc}
\hline No & Pekerjaan & Frekuensi & Persentase \\
\hline 1 & PNS & 10 & $25 \%$ \\
\hline 2 & Advokad & 6 & $15 \%$ \\
\hline 3 & Swasta/wiraswasta & 14 & $35 \%$ \\
\hline 4 & Masih sekolah/kuliah & 10 & $25 \%$ \\
\hline 5 & Tidak Bekerja & 0 & $0 \%$ \\
\hline & JUMLAH & 40 & $100 \%$
\end{tabular}

Sumber : Hasil Penelitian, 2014

Pada tabel 4 diatas menunjukkan bahwa pekerjaan responden, terdiri atas
$35 \%$ responden bekerja di sektor swasta/wiraswasta, $25 \%$ responden 
adalah Pegawai Negeri Sipil, $25 \% \quad 15 \%$ responden bekerja sebagai responden masih sekolah/kuliah, dan Advokad/Pengacara.

Tabel 7.

Informasi Penanganan Tipikor di Kepolisian dan Kejaksaan di Provinsi Kalimantan Selatan

\begin{tabular}{llcc}
\hline No & Informasi Penanganan Tipikor & Frekuensi & Persentase \\
\hline 1 & Ya & 40 & $100 \%$ \\
\hline 2 & Tidak & 0 & $0 \%$ \\
\hline & JUMLAH & 40 & $100 \%$
\end{tabular}

Sumber : Hasil Penelitian, 2014

Berkaitan dengan informasi yang Kalimantan Selatan, seluruh respon didapatkan responden atas penanganan menyatakan mengetahui informasi tersebut. (lihat tabel 5 diatas)

perkara tindak pidana korupsi di Provinsi

Tabel 8

\section{Sumber Mendapatkan Informasi}

\begin{tabular}{llcc}
\hline No & Sumber mendapatkan informasi & Frekuensi & Persentase \\
\hline 1 & Media elektronik & 15 & $37,5 \%$ \\
\hline 2 & Media cetak & 19 & $47,5 \%$ \\
\hline 3 & Sumber langsung & 6 & $15 \%$ \\
& & & $100 \%$
\end{tabular}

Sumber : Hasil Penelitian, 2014

Sumber mendapatkan informasi atas berupa surat kabar, majalah, dan tabloid. penanganan perkara tindak pidana Dan $37,5 \%$ responden mendapatkan korupsi di Provinsi Kalimantan Selatan, informasi bersumber pada media berdasarkan pada tabel 6 ditemukan elekronik yakni radio dan televisi lokal, bahwa $47,5 \quad \% \quad$ responden sedangkan $15 \%$ responden mendapatkan mendapatkannya dari media cetak informasi langsung karena mereka 
bekerja sebagai advokat/pengacara yang pidana korupsi.

mendapingi kliennya yang terlibat tindak

Tabel 9.

Memantau Perkembangan Tahapan Penanganan Tipikor di Kepolisian dan Kejaksaan di Provinsi Kalimantan Selatan

\begin{tabular}{|l|l|c|l|}
\hline No & & Frekuensi & Persentase \\
\hline 1 & memantau seluruh proses tahapan & 6 & $15 \%$ \\
\hline 2 & memantau sebagian proses tahapan & 29 & $72,5 \%$ \\
\hline 3 & Tidak memantau & 5 & $12,5 \%$ \\
\hline & JUMLAH & 40 & $100 \%$ \\
\hline
\end{tabular}

Sumber : Hasil Penelitian, 2014

Berdasarkan hasil penelitian penyidikan, penuntutan, dan menunjukkan bahwa, $29 \%$ responden pemeriksaan di pengadilan. Hanya menyatakan bahwa memantau sebagian $\quad 12,5 \%$ responden yang tidak melakukan proses tahapan penanganan perkara, pemantauan, mereka hanya sekedar tahu sedangkan $15 \%$ responden menyatakan saja tanpa mengikuti proses penanganan memantau dan mengikuti seluruh proses perkara. tahapan penanganan perkara mulai dari

Tabel 10

Kinerja Kepolisian di Provinsi Kalimantan Selatan dalam Penanganan Perkara Tipikor

\begin{tabular}{llcc}
\hline No & & Frekuensi & Persentase \\
\hline 1 & Baik & 10 & $25 \%$ \\
\hline 2 & Cukup & 25 & $62,5 \%$ \\
\hline 3 & Kurang & 5 & $12,5 \%$ \\
\hline & JUMLAH & 40 & $100 \%$
\end{tabular}

Sumber : Hasil Penelitian, 2014. 
Atas kinerja Kepolisian selaku penyelidik dan penyidik tindak pidana korupsi di Provinsi Kalimantan Selatan, hasil penelitian menunjukkan bahwa 62,5\% responden menilai kinerja

Tabel 11

\section{Kinerja Kejaksaan di Provinsi Kalimantan Selatan dalam Penanganan Perkara}

\section{Tipikor}

\begin{tabular}{|l|l|l|l|}
\hline No & & Frekuensi & Persentase \\
\hline 1 & Baik & 10 & $25 \%$ \\
\hline 2 & Cukup & 25 & $62,5 \%$ \\
\hline 3 & Kurang & 5 & $12,5 \%$ \\
\hline & JUMLAH & 40 & $100 \%$ \\
\hline
\end{tabular}

Sumber : Hasil Penelitian, 2014

Demikian pula atas kinerja Kejaksaan selaku penyelidik, penyidik, dan penuntut tindak pidana korupsi di Provinsi Kalimantan Selatan, hasil penelitian juga menunjukkan hal yang sama bahwa $62,5 \%$ responden menilai kinerja Kejaksaan adalah cukup, 25\% responden menilai kinerja Kejaksaan adalah baik, dan $12,5 \%$ responden menilai kinerja Kejaksaan adalah kurang.

Responden yang menyatakan cukup berangapan bahwa kinerja Kepolisian dan Kejaksaan dalam penanganan perkara tindak pidana korupsi di Provinsi Kalimantan Selatan masih belum efektif dan efisien karena
Kepolisian adalah cukup, 25\% responden menilai kinerja Kepolisian adalah baik, dan $12,5 \%$ responden menilai kinerja Kepolisian adalah kurang. 
Tindak pidana korupsi yang terjadi di Indonesia, khususnya di Provinsi Kalimantan Selatan saat ini mengindikasikan keadaan yang luar biasa (extra ordinary crime), sehingga model penanganan perkara tindak pidana korupsi yang sudah dilakukan oleh Kepolisian dan Kejaksaan di Provinsi Kalimantan Selatan selama ini perlu dilakukan rekonstruksi agar penanganan perkara tindak pidana korupsi di Kalimantan Selatan lebih efektif dan efisien.

Rekonstruksi (Alwi, :942) model penanganan perkara tindak pidana korupsi pada dasarnya adalah membangun atau menata kembali model penanganan perkara tindak pidana korupsi yang sudah ada, dengan tujuan memperbaharui atau memperbaikinya agar lebih sesuai dengan perkembangan dan kebutuhan masyarakat.

Merekonstruksi adalah membentuk kembali, membangun kembali dapat berupa fakta-fakta ataupun ide-ide atau melakukan remodel (Black, 1990 : 1272). Konsep rekonstruksi model penanganan perkara tindak pidana korupsi pada dasarnya adalah upaya membentuk atau menyusun suatu model penanganan perkara tindak pidana korupsi yang relatif berbeda dengan model pada proses peradilan pidana yang sudah ada, yakni membangun atau menata suatu model baru yang relatif berbeda dengan model yang selama ini dipergunakan untuk penanganan perkara tindak pidana korupsi agar lebih sesuai dengan perkembangan dan kebutuhan masyarakat.

Model yang cocok untuk diterapkan dalam penanganan perkara tindak pidana korupsi di Provinsi Kalimantan Selatan adalah Crime Control Model (CCM). Perwujudan model CCM adalah mengutamakan kecepatan dan efisiensi, sehingga kewenangan penyelidikan, penyidikan, dan penuntutan digabung dalam satu atap yakni sebuah tim yang dibentuk bersama antara Kepolisian dan Kejaksaan dengan maksud mempercepat proses penanganannya karena tindak pidana korupsi termasuk sulit dalam pembuktiannya dan memerlukan kerjasama yang solid kedua lembaga penegak hukum tersebut.

Untuk itu sebagai perwujudan negara hukum Indonesia hendaklah dibangun model penyelesaian dengan fokus penataan ranah kerja meliputi sinkronisasi antar lembaga hukum dalam kerja sama untuk penegakan hukum, 
peradilan dan pemberantasan korupsi. Semua proses yang berjalan di masingmasing lembaga harus bisa sejalan dan tidak malah saling mengganggu satu sama lain. Oleh karena itu perlu adanya pola atau model sistem penanganan perkara tindak pidana korupsi melalui Joint Investigation Teams.

Penanganan perkara tindak pidana korupsi melalui Joint Investigation Teams, menggabungkan kedua lembaga penegak hukum yakni Kepolisian dan Kejaksaan dalam satu atap agar pemberantasan tindak pidana korupsi akan semakin meningkat, membaik, dan cepat dalam proses pengungkapannya. Selain itu juga, visi dan misi Polri dan Kejagung memiliki kesamaan dalam hal pemberantasan tindak pidana korupsi, sehingga yakin bisa bersinergi.

Model ideal penanganan perkara tindak pidana korupsi di Provinsi Kalimantan Selatan melalui Joint Investigation Teams dalam sistem peradilan pidana Indonesia dapat dilakukan dengan dua model pilihan, yakni:

a. Model Koordinatif

Pada model ini lembaga penyidik merupakan gabungan dari penyidik kepolisian dan penyidik kejaksaan, sedangkan lembaga penuntut ada pada Kejaksaan, dengan KPK sebagai koordinator dan supervisi. Lembaga ini bertanggungjawab pada Mahkamah Agung

b. Model Kolegial

Pada model ini penyidikan dilakukan oleh suatu badan yang disebut sebagai badan penyidikan yang anggotanya terdiri dari penyidik Kepolisian dan Penyidik Kejaksaan, sedangkan penuntutan atau badan penuntutan ada pada Kejaksaan. Kepemimpinan yang bersifat kolegial terdiri dari unsur Kepolisian dan Kejaksaan, dan KPK dapat diberikan tugas untuk koordinasi dan supervisi, badan ini bertanggungjawab pada Mahkamah Agung.

Penegakan hukum tindak pidana korupsi berbasis Joint Investigation Teams melibatkan beberapa pihak yang terkait. Pihak-pihak tersebut antara lain: Kejaksaan dan Kepolisian, serta KPK. Setiap pihak yang terlibat memiliki peran dan fungsi yang saling berkaitan dalam satu sistem yaitu sistem dalam penanganan tindak pidana korupsi. 


\section{Simpulan}

Berdasarkan hasil penelitian yang dilaksanakan, maka ada beberapa hal yang dapat disimpulkan sebagai berikut :

a. Kendala yang dihadapi oleh aparat penegak hukum dalam penanganan perkara tindak pidana korupsi di Banjarmasin adalah Adanya multiplikasi lembaga penyidikan tipikor yang berpotensi menimbulkan egoisme sektoral dalam penyerahan perkara dari penyidik pada jaksa penuntut umum dan belum adanya formulasi peraturan perundangan yang integral dalam penyidikan tipikor yang dapat mengeleminir munculnya egoisme sektoral.

b. Faktor pendukung dalam penanganan tindak pidana korupsi bagi institusi penegak hukum, yaitu Kepolisian dan Kejaksaan adalah sarana dan prasarana yang cukup, dan peran serta masyarakat dalam membuat laporan terkait adanya indikasi Tindak Pidana Korupsi.

c. Model penegakan penanganan tindak pidana korupsi dapat mengakomodasi model koordinatif dan model kolegial.

\section{Daftar Rujukan}

Black, Henry Campbell, Black's Law Dictionary, Edition 6, Minnesotta: West Publishing, 1990.

Lexy J. Moleong, Metode Penelitian Kualitaitf, Bandung: PT. Remaja Rosdakarya, 1997.

http://nasional.kompas.com/read/2014/0 1/03/1547079/Mendongkrak.Indeks. Persepsi.Korupsi, diakses tangal 12 Juli 2014.

Kitab Undang-Undang Hukum Pidana

Undang-Undang Nomor 8 Tahun 1981 tentang Hukum Acara Pidana

Undang-Undang Nomor 31 Tahun 1999 tentang Pemberantasan Tindak Pidana Korupsi

Undang-Undang Nomor 20 Tahun 2001 tentang Perubahan atas UndangUndang Nomor 31 Tahun 1999 tentang Pemberantasan Tindak Pidana Korupsi

Undang-Undang Nomor 2 Tahun 2002 tentang Kepolisian Negara Republik Indonesia

Undang-Undang Nomor 30 Tahun 2002 tentang Komisi Pemberantasan Tindak Pidana Korupsi

Undang-Undang Nomor 16 Tahun 2004 tentang Kejaksaan Republik Indonesia. 